فصلنامه گياهان دارويى

بهينه تغيير حجم هوادهى و دماى بيوراكتور

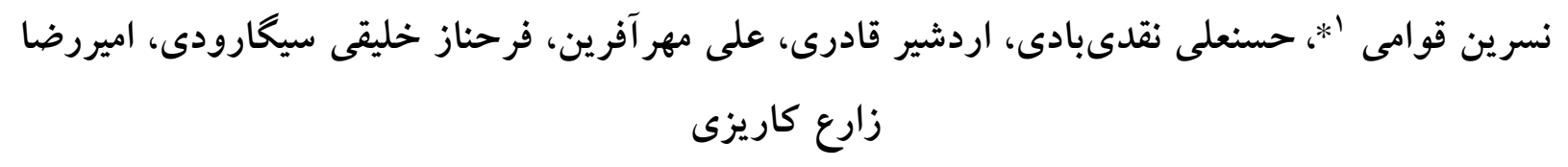

1- مركز تحقيقات گياهان دارويى، ئوهشكده گياهان دارويى جهاددانشگاهى كرج، ايران

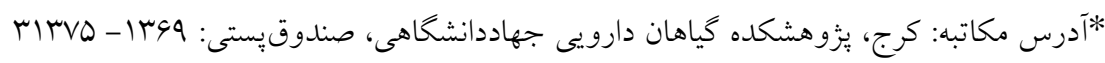

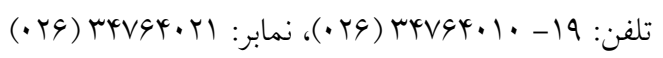
يست الكترونيك: nassrinqavami@gmail.com

doi: 10.29252/jmp.2.70.173 9V/11/1 تاريخ تصويب تاريخ دريافت: PV/N/IK

جكيده

مقدمه: امروزه بهينهسازى شرايط كثت در بيوراكتورها به عنوان يك راهكار مهم براى توليد متابوليتهاى ثانويه از جمله تبائين

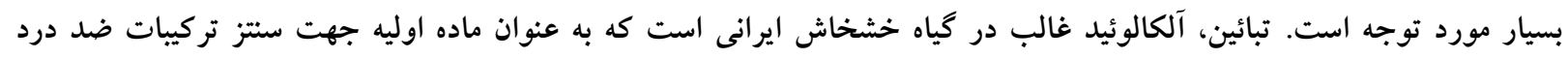
مورد استفاده قرار مى ميرد.

هدف: بهينه سازى شرايط كشت ريشه نابجا خشخاش كبير در بيوراكتور در راستاى افزايش توليد تبايين.

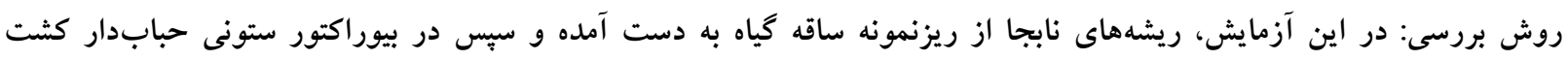

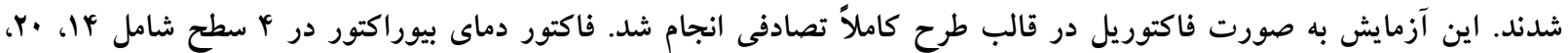

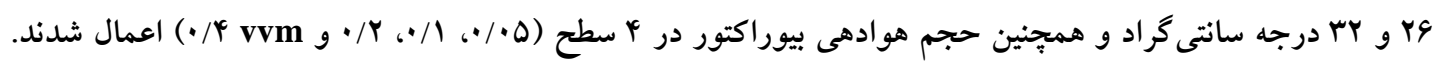

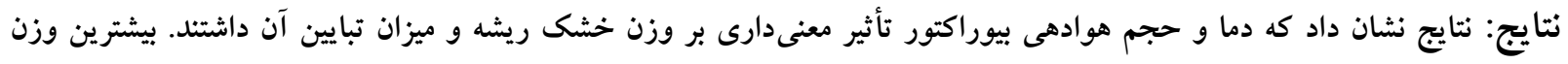

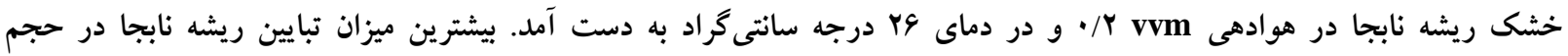
هو ادهى

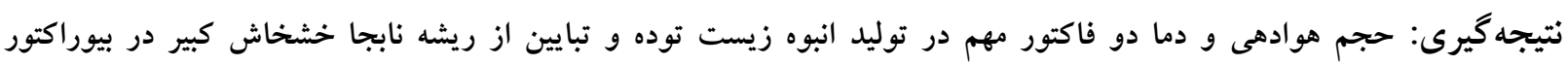
مىباشد. كل وازگًان: بيوراكتور، تبايين، خشخاش كبير، ريشه نابجا 
يزوهش با هدف بهينهسازى رشد و توليد ماده تبايين از ريشههاى نابجا كياه خشخاش كبير در بيوراكتور انجام شده است.

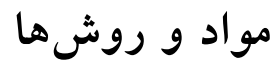

بذر كياه خشخاش كبير از بانك بذر يزوهشكده كياهان دارويى جهاد دانشخاهى (با كد MPISB-1328) تهيه شد. منشأ بذرهاى مورد استفاده، منطقه انجمنه در كردستان بود.

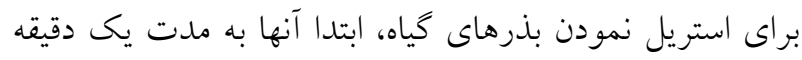

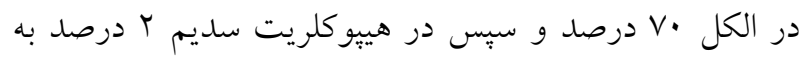

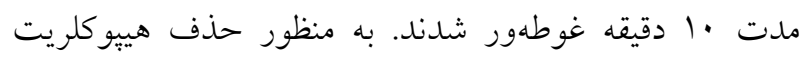
سديم، بذرهاى ضدعفونى شده، ه مرتبه با آب مقطر استريل شتشو داده شدند. بذرها بعد از ضدعفونى شدن، در محيط 1/T MS

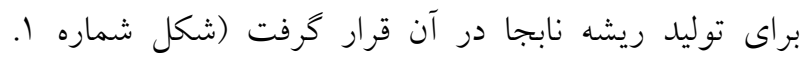

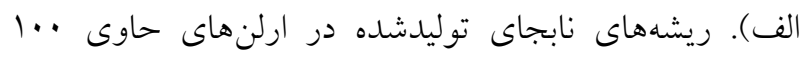
ميلىليتر محيط مايع MS حاوى هورمون اكسين كشت شائ شدندائد

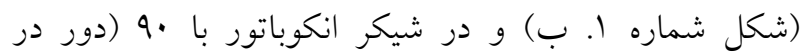

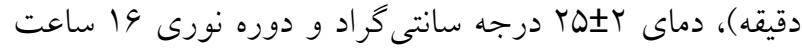
روشنايى و 1 ساعت تاريكى قرار كرفتند. به منظور بررسى اثر حجم هوادهى و دما بر رشد ريشه و

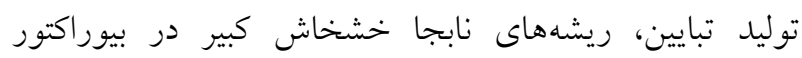

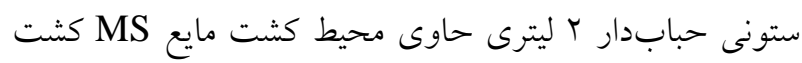

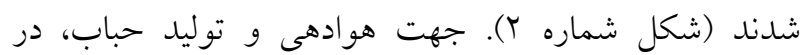

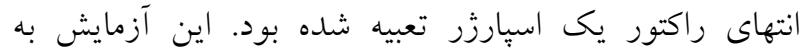
صورت فاكتوريل در قالب طرح كاملاً تصادفى با سه تكرار

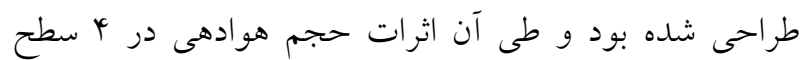
vvm (Volume air per Volume culture per Minute)

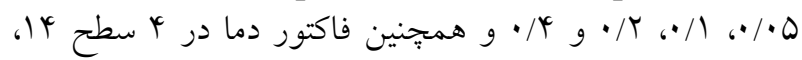

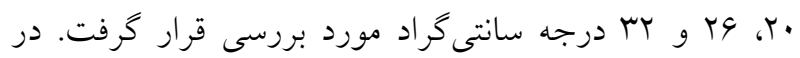

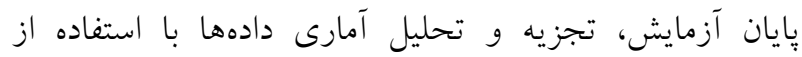
نرمافزار SAS و مقايسه ميانكينها با روش جنداردامنهاى دانكن در سطح احتمال ه درصد انجام شد.

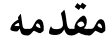

Papaver bracteatum Lindl. خشخاش ايرانى با نام علمى

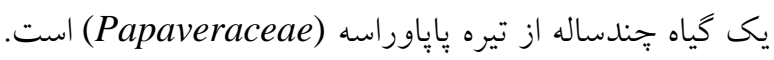

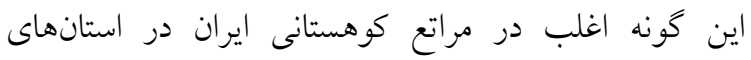

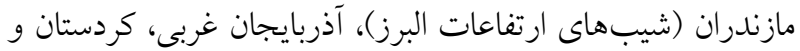

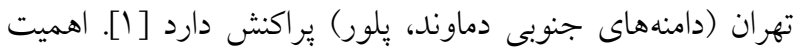

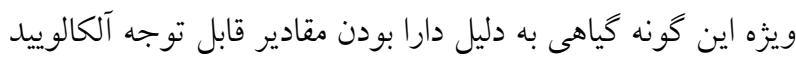

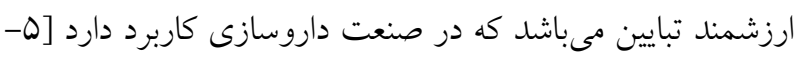

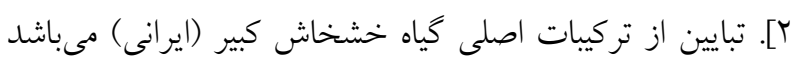

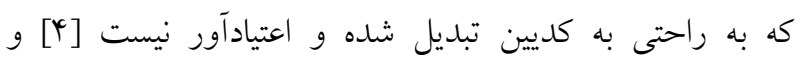

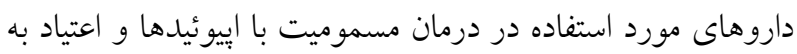
آنها، مانند نالوكسون (Naloxone)، نالتركسون (Nalteroxone)

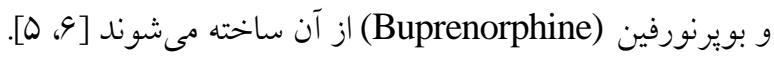
در سالهاى اخير، تكنولوزى كشت سلول، بافت و اندام

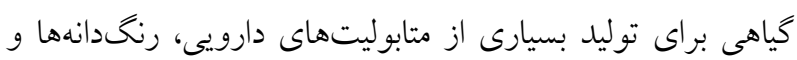

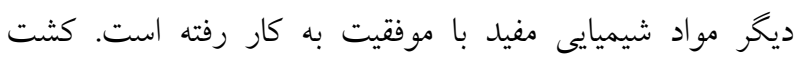

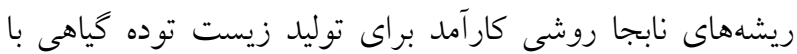

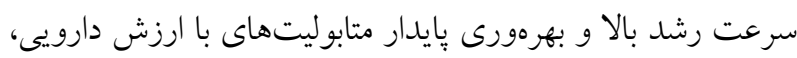

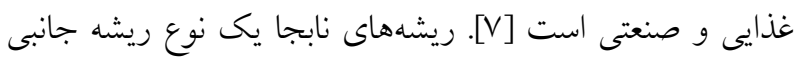

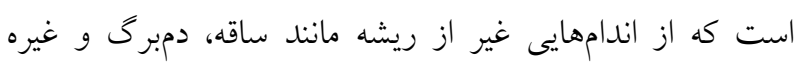

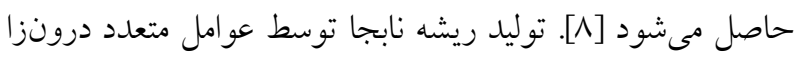

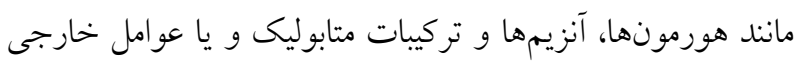

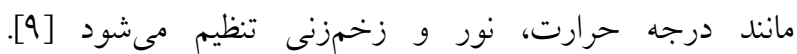
بيوراكتورها اغلب براى توليد در مقياس زياد متابوليتهاى كياهى

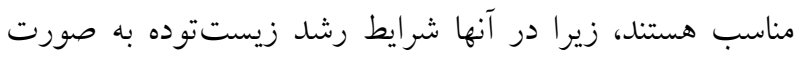

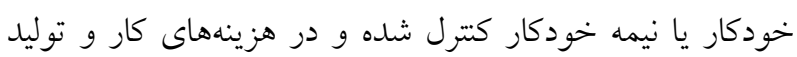
صرفهجويى مىشود [ [1].

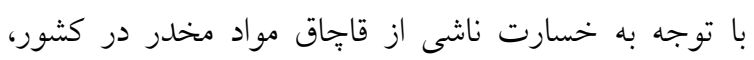

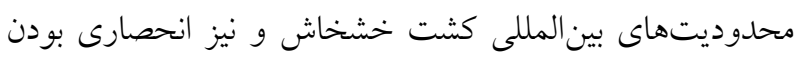

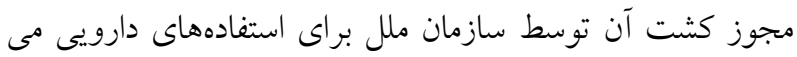
توان با به كارگيرى فن آورىهاى كشت درون شيشهاى (مانند

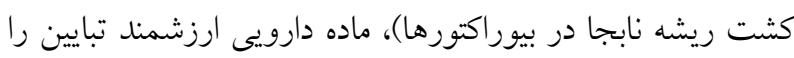

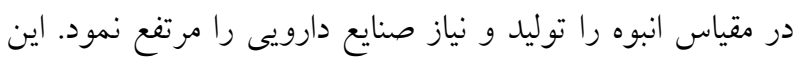


قوامى و همكاران
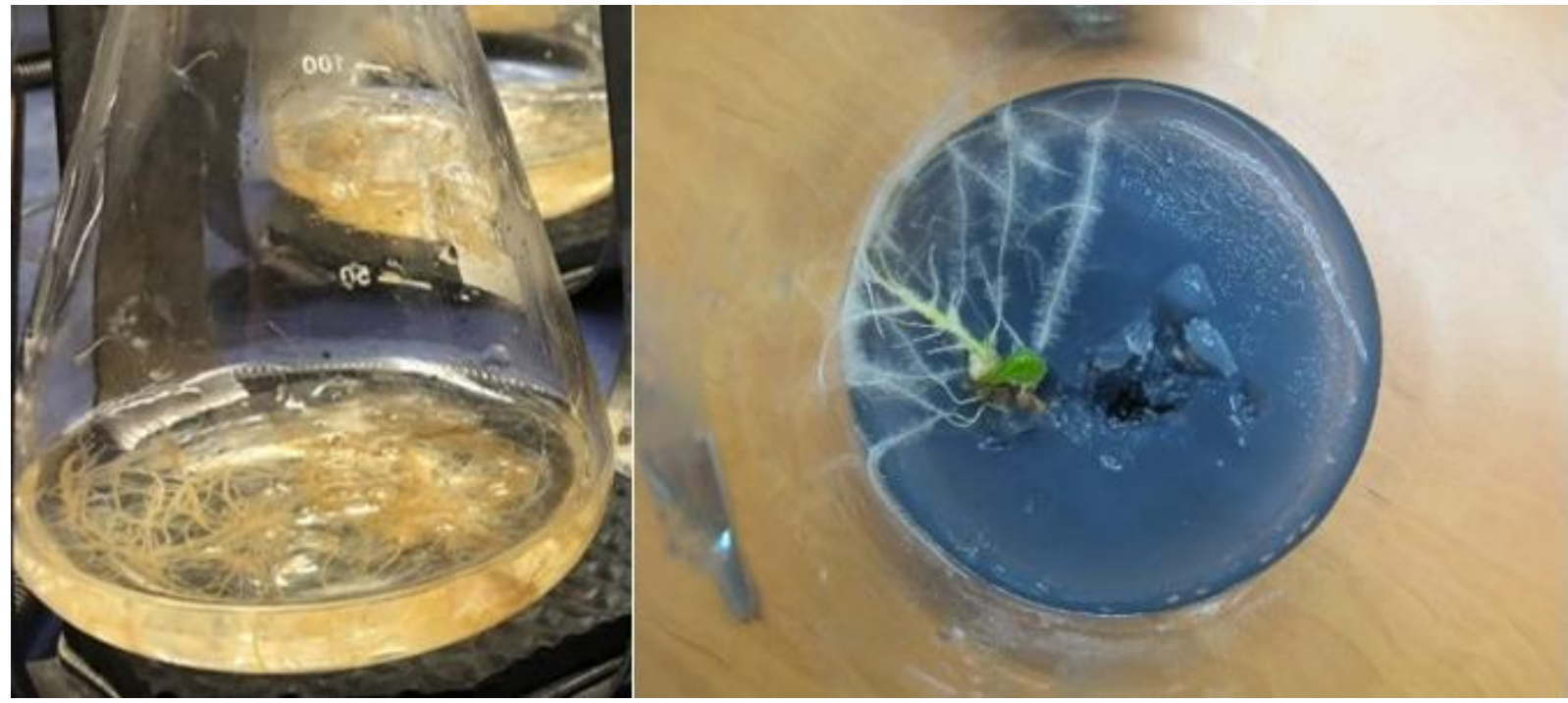

شكل شماره ا- الف. ريشه نابجاى حاصل از ريزنمونه ساقه كياه خشخاش كبير ب. كشت ريشهاى نابجا در محيط كشت مايع

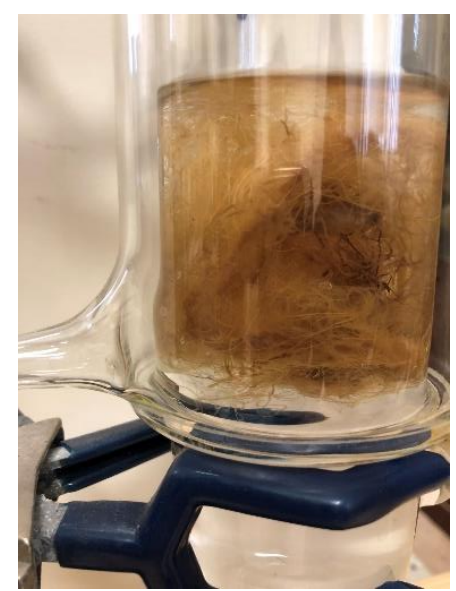

شكل شماره Y - ريشهاى نابجاى توليد شده در بيوراكتور ستونى حبابدار

به يك دكانتور منتقل كرده و يس از ايجاد دو فاز مجزا،

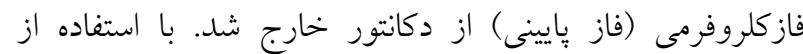

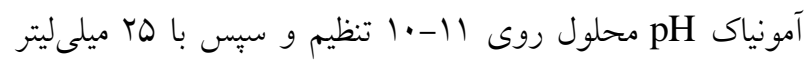

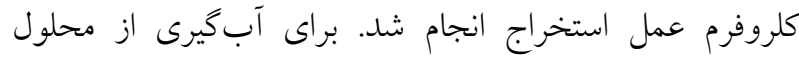

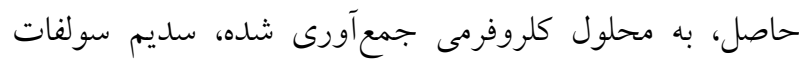

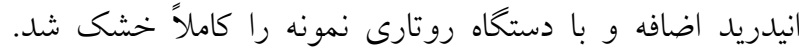
عصاره خشك به دست آمده را در يك ميلى ليتر متانول حل كرده روناه

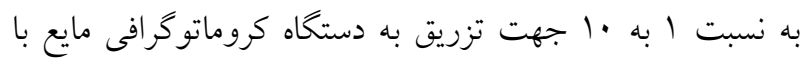

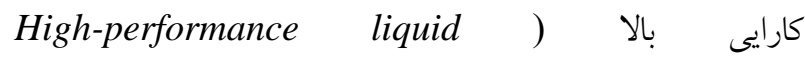
(HPLC) chromatography
اندازهيرى تبايين

نمونهاى زيست توده ريشه نابجا بعد از جمع آورى از تباين

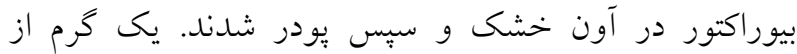

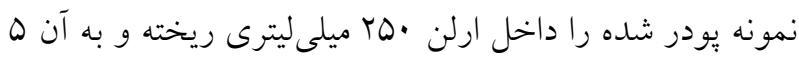

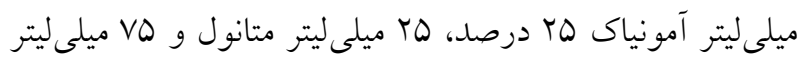

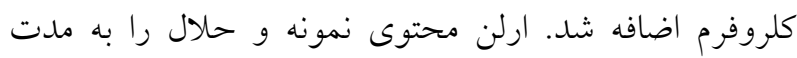

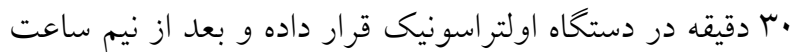
بوسيله كاغذ صافى صاف شد و محلول صاف شده را به يك ديك

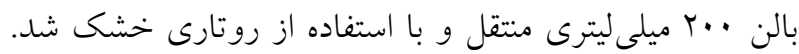

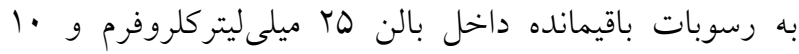

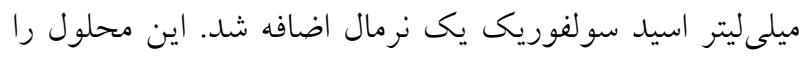


بيشترين وزن خشك ريشه T/V و ب كرم به ترتيب در حجم

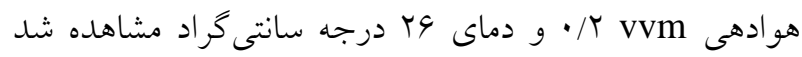
اثر حجم هوادهى و دما بر وزن خشك ريشه نابجا

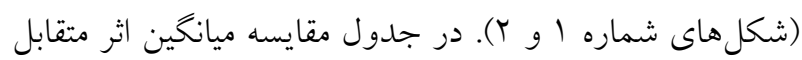

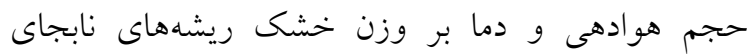

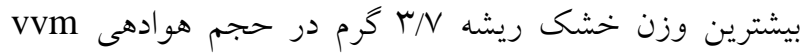

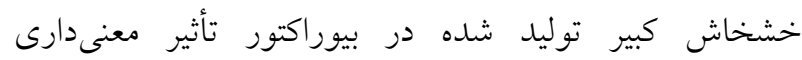

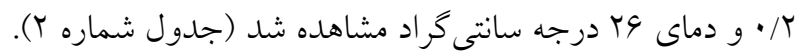

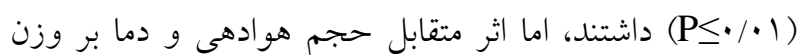
خشى ريشهاى نابجا معنىدار نشد (جدول شماره (1). جدول شماره ا- جدول تجزيه واريانس اثر دما و حجم هوادهى بر صفات مورد ارزيابى ريشه نابجا خشخاش كبير

\begin{tabular}{|c|c|c|c|}
\hline وزن خشك & تبائين & درجه آزادى & منابع تغيير \\
\hline$\Lambda \cdot r \Lambda^{* *}$ & $11 \cdot / 9 r V^{* *}$ & $r$ & دما \\
\hline T/GYQ** & $9 / 19 \mu^{* * *}$ & r & هو ادهى \\
\hline - / TYY ns & $\cdot$ /VVA ns & 9 & دما × هو ادهى \\
\hline$\cdot / D Q F$ & $\cdot / 4 V G$ & rt & خطا \\
\hline $11 / \cdot 9$ & $1 N / 9 V$ & & ضريب تغييرات \\
\hline
\end{tabular}

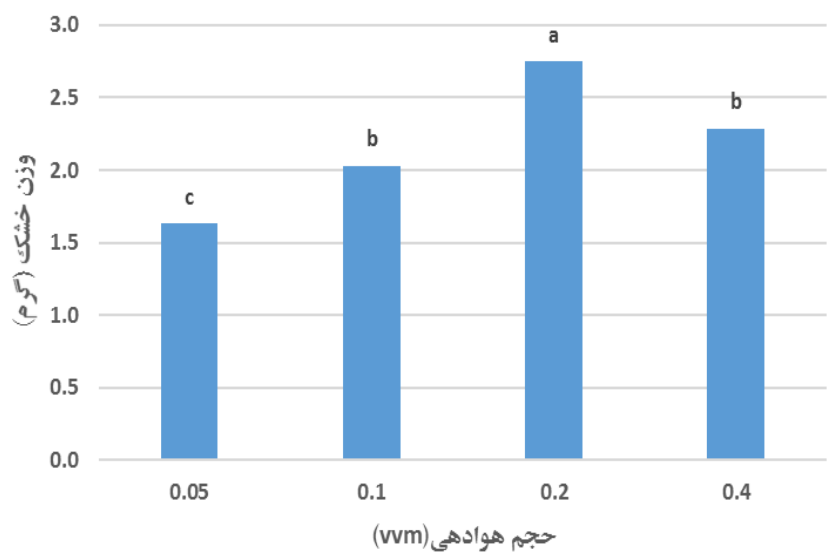

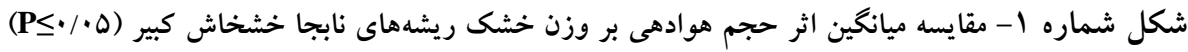

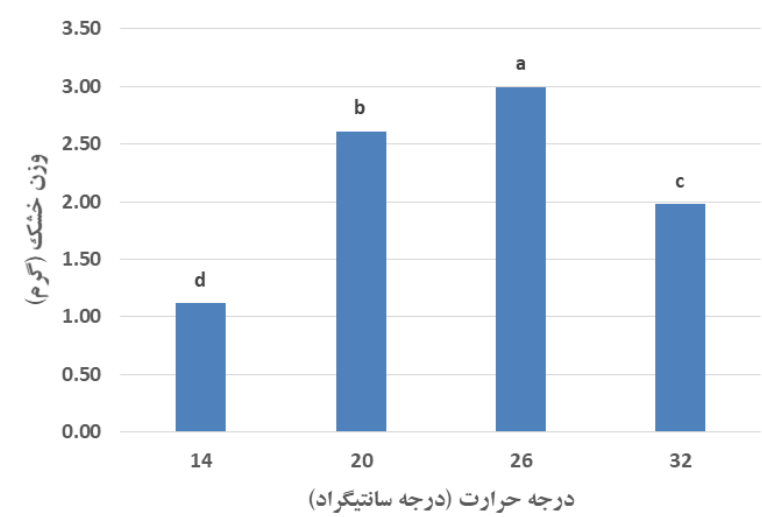

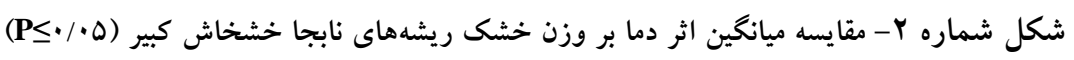


قوامى و همكاران

هوادهى نشان داد كه بيشترين ميزان تبايين MNY ميلى گرم/ كرم در حجم

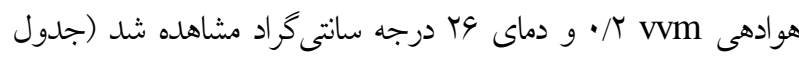

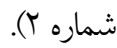
با افزايش دما از •T به צY درجه سانتى گراد ميزان تبايين ريشه به طور منىى دارى افزايش و سبس با با فزايش دما به كب درجه سانتى كراد كاهش يافت. به هر حال بيشترين ميزان تبايين ريشه نابجا در دماى وب درجه

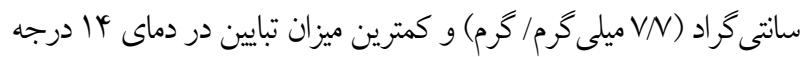

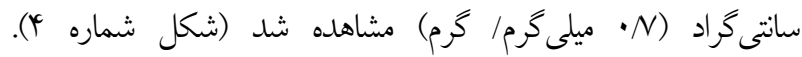
كروماتو گرام HPLC تبايين از ريشه نابجا در شكل شماره ها آمده است.
اثر حجم هوادهى و دما بر ميزان تبايين ريشه نابجا

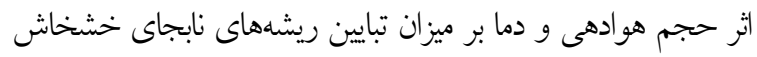

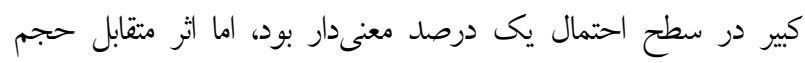
هو ادهى و دما بر تبايين ريشهاى نابجا معنىدار نبود (جدول شماره ().

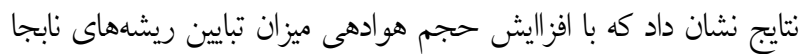

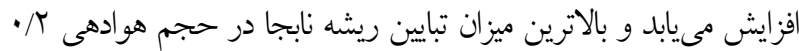

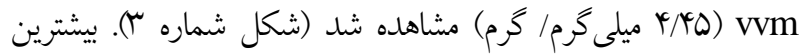

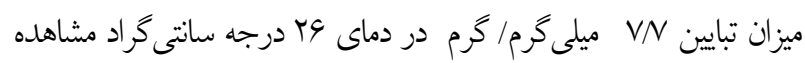

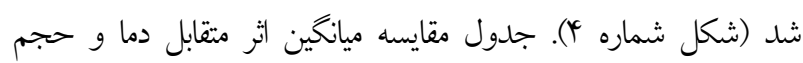
جدول شماره Y- جدول مقايسه ميانكين اثر متقابل دما و حجم هو ادهى بر مقدار وزن خشك و تبائين ريشه نابجا خشخاش كبير

\begin{tabular}{|c|c|c|c|}
\hline وزن خشك (گرم) & تبانين (ميلى كرم/ كرم) & حجم هوادهى (vvm) & دما (درجه سانتيخراد) \\
\hline$\cdot / \wedge \& g$ & $\cdot / 90 \mathrm{~g}$ & .1 .0 & \multirow{4}{*}{ if } \\
\hline $1 / \cdot r g$ & $\cdot / V \backslash g$ & $\cdot / 1$ & \\
\hline l/4kefg &.$/ 91 \mathrm{~g}$ & $\cdot / r$ & \\
\hline $1 / 1 \Delta f g$ & $\cdot / V Y g$ & $\cdot / 4$ & \\
\hline l/Ardef & $1 / 1 \mathrm{Vfg}$ & $.1 \cdot 0$ & \multirow{4}{*}{$r}$. \\
\hline$r / \Gamma \cdot c d$ & I/Vrefg & $\cdot / 1$ & \\
\hline$r / r \wedge a b$ & r/Arde & $\cdot / r$ & \\
\hline$r / 99 \mathrm{bc}$ & T/T\&def & $\cdot / 4$ & \\
\hline r/rצcd & $q / \pi \Delta b$ & $.1 \cdot 0$ & \multirow{4}{*}{ rq } \\
\hline $\mathrm{r} / \mathrm{a} \mathrm{cbc}$ & V/ara & $\cdot / 1$ & \\
\hline$r / v \cdot a$ & N/vía & $\cdot / r$ & \\
\hline $\mathrm{r} / \mathrm{q} 9 \mathrm{bc}$ & V/VGa & $\cdot / 4$ & \\
\hline $1 / 49$ efg & r/Arde & .1 .0 & \multirow{4}{*}{ rr } \\
\hline l/Ardef & $r / \mathcal{Y} \Delta \mathrm{d}$ & $\cdot / 1$ & \\
\hline$r / \Delta \& \mathrm{~cd}$ & $\Delta / \Gamma \Delta b c$ & $\cdot / r$ & \\
\hline$r / \cdot r \mathrm{de}$ & F/Nrc & $\cdot / 4$ & \\
\hline
\end{tabular}

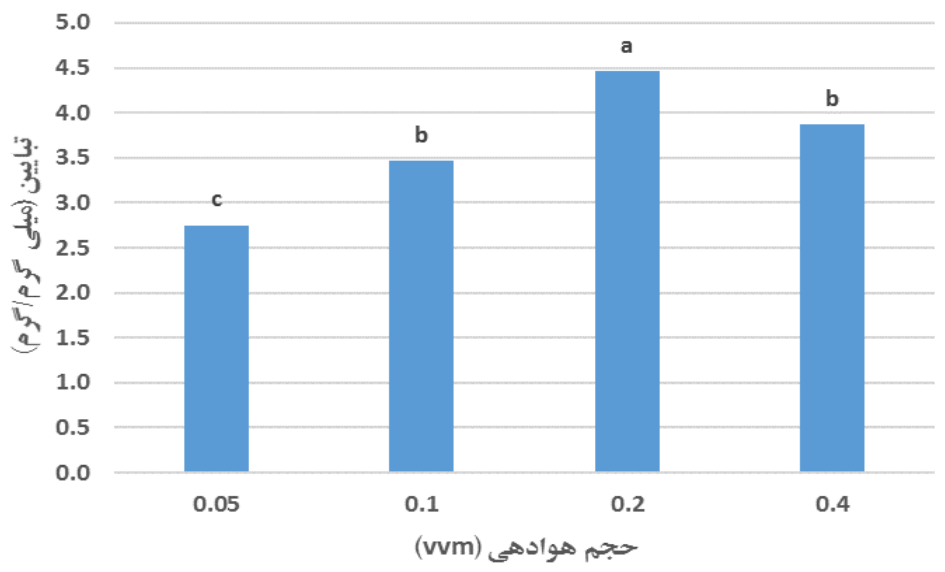

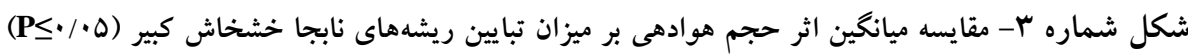




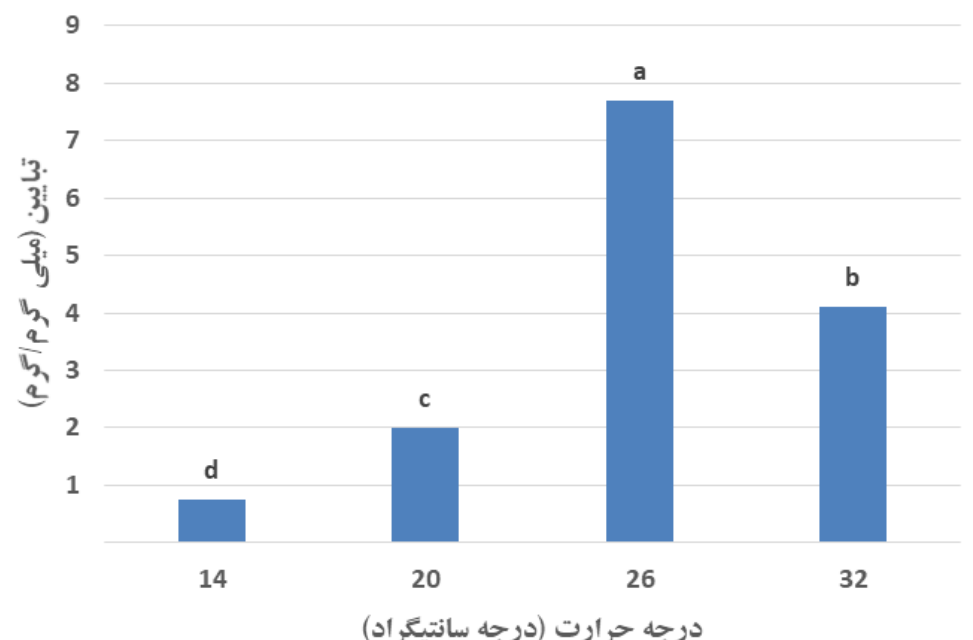

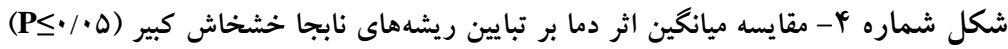

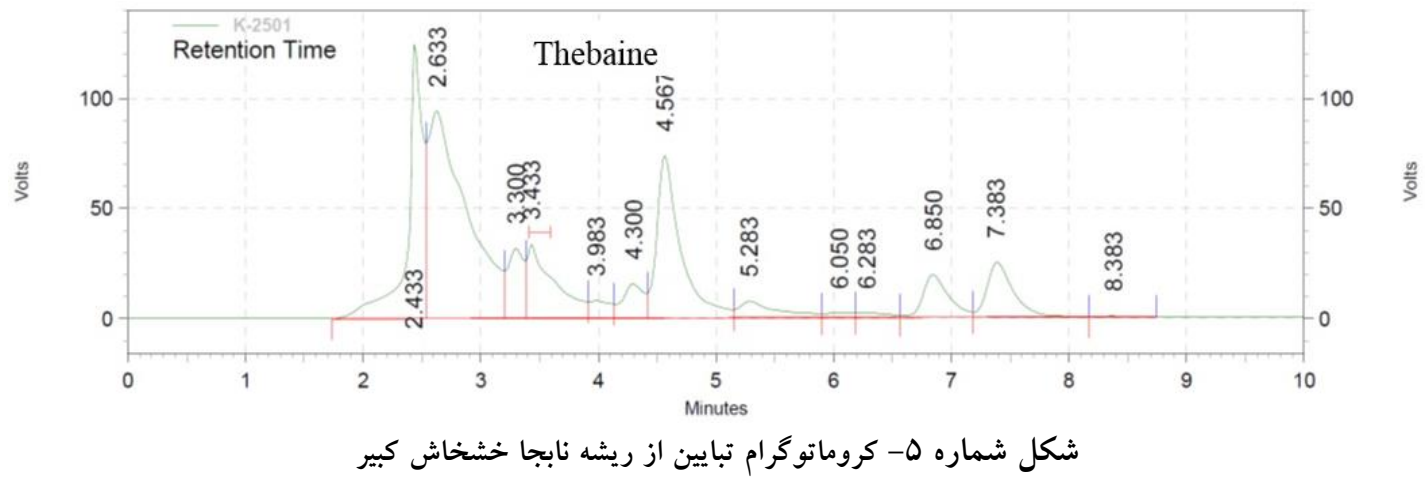

ميزان رشد در سرعتهاى هوادهى بايين كمتر خواهد بود.

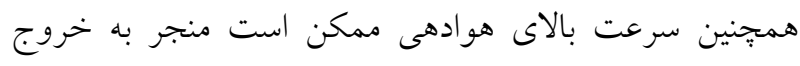
CO2

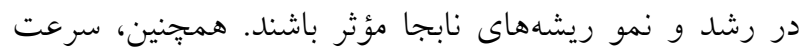

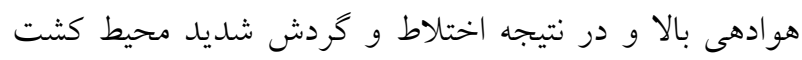

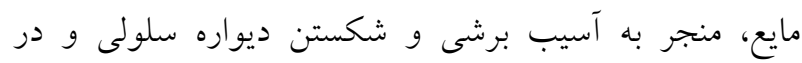
نتيجه تجمع بقاياى سلولى مى شود. تجمع بقاياى سلولى بلى و و

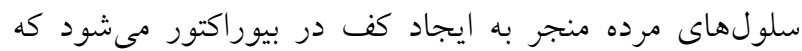

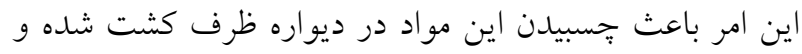

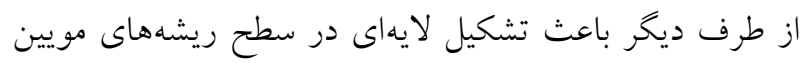
شده كه مى تواند از رسيدن اكسيزن و مواد مغذى به ريشهها

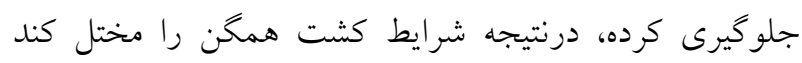

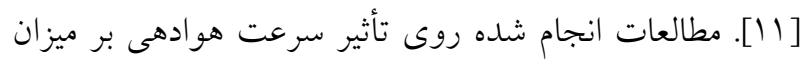

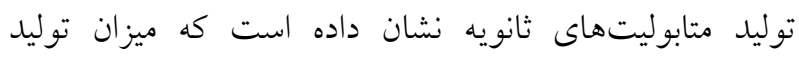

عواملى كه روى انتقال اكسيزن به ريشههاى نابجا در

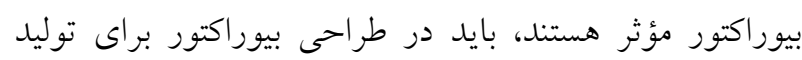

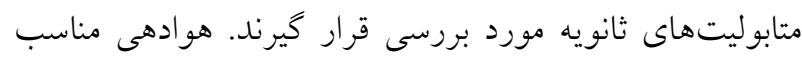

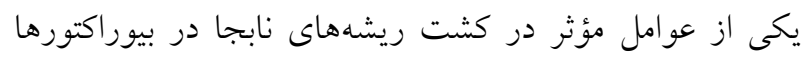

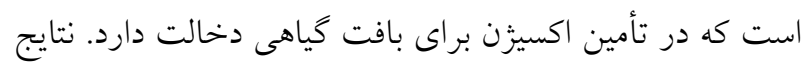

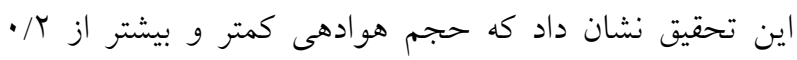

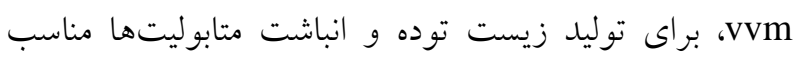

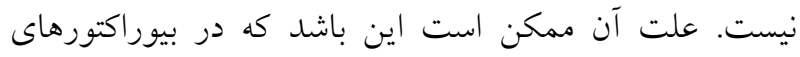

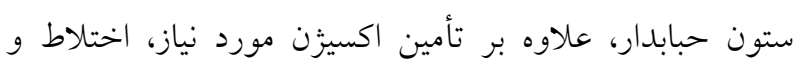

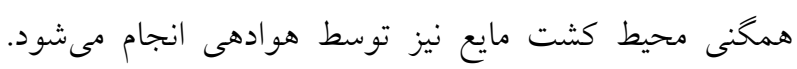

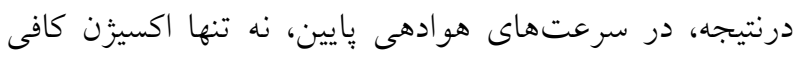

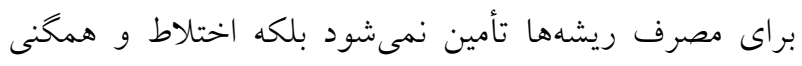
محيط كشت مايع نيز به طور ضعيف انجام مىشود. بنابراين، 


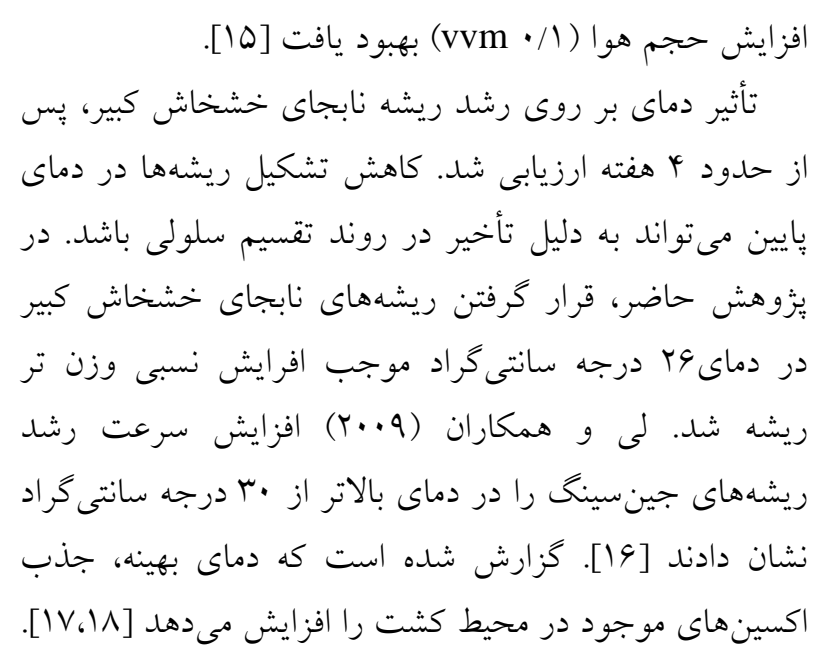

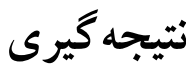

بهينه كردن شرايط توليد ريشههاى نابجا براى افزايش

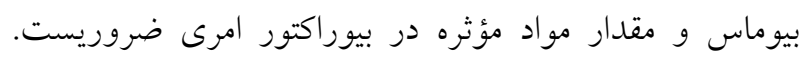

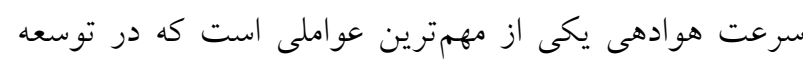

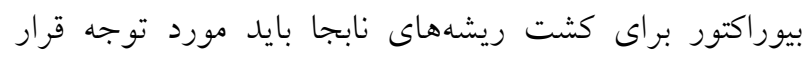

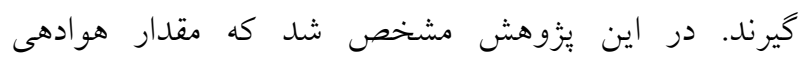

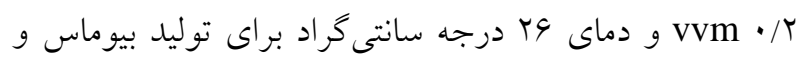

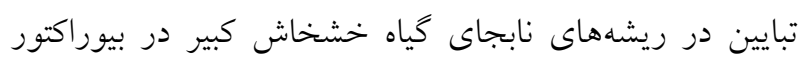
ستون حبابدار مناسب هستند.
متابوليت با افزايش سرعت هوادهى كاهش مىيابد، به عنوان

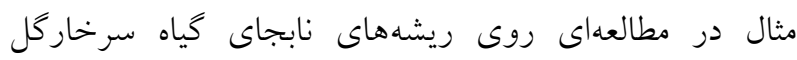

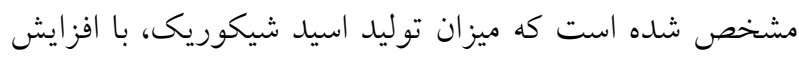

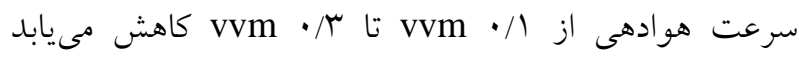
[1/[1]. نتايج اين آزمايش نشان دان داد كه توليد كمتر اسيد

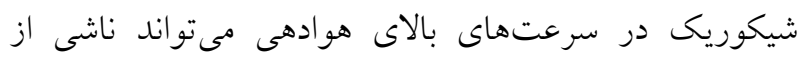

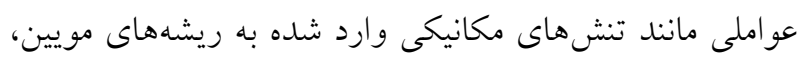

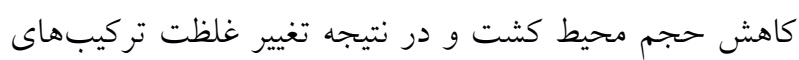

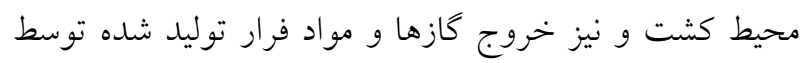
ريشه هاى مويين باشد كه بر توليد متابوليت هاى ثانويه مؤثرند.

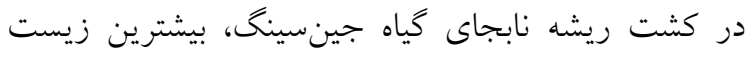

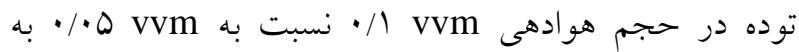

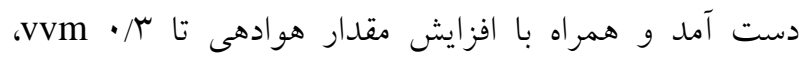

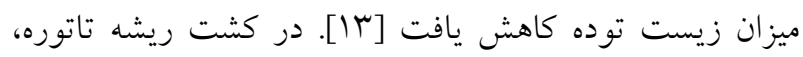

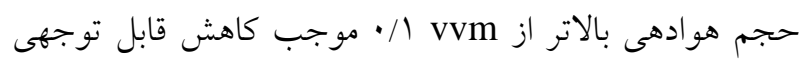
در مقدار توليد متابوليت شد، در حالى كه حداكثر رشد و توليد

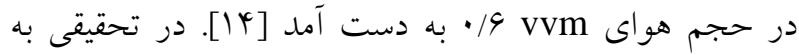
منظور بهينهسازى سيستم كشت براى توليد هاييريسين از ريشه

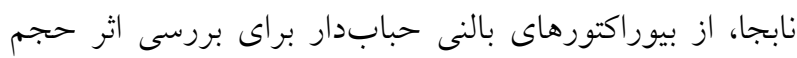

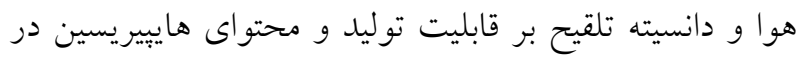

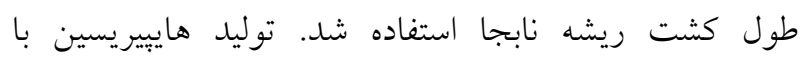

\section{منابع}

1. Mozaffarian V. A Dictionary of Iranian Plant Names 2012, Iran: Farhang Moaser Press.

2. Fairbairn J W and Hakim F. Papaver bracteatum Lindl.-a new plant source of opiates. J. Pharm. Pharmacol. 1973; 25: 353-8.

3. Nyman U and Bruhn J G. Papaver bracteatum Lindl.-a summary of current knowledge. Planta Medica. 1979; 35: 98-117.

4. Kapoor L D. Opium Poppy: botany, chemistry and pharmacology. 1997, USA: Food Products Press.

5. Kettenes-van de Bosch J, Salemink J C A and Khan I. Biological activity of the alkaloids of
Papaver bracteatum Lind. Journal of Ethnopharmacology 1981; 3 (1): 21-38.

6. Palevitch D and Levy A. Domestication of Papaver bracteatum as a source of thebaine. Acta Horticulturae. 1992; 306: 33-52.

7. Murthy $\mathrm{H} \mathrm{N}$ and Praveen N. Carbon sources and medium $\mathrm{pH}$ affects the growth of Withania somnifera (L.) Dunal adventitious roots and withanolide A production. Natural Product Res. 2008; 27 (2): 185-9.

8. Ramirez-Carvajal G A, Morse A M, Dervinis $\mathrm{C}$ and Davis $\mathrm{J}$ M. The cytokinin type-B response regulator PtRR13 is a negative regulator of

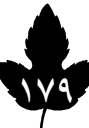


adventitious root development in Populus. Plant Physiol. 2009; 150 (2): 759-771.

9. Deepthi $\mathrm{S}$ and Satheeshkumar K. Effects of major nutrients, growth regulators and inoculum size on enhanced growth and camptothecin production in adventitious root cultures of Ophiorrhiza mungos L. Biochemical Engineering J. 2017; 117: 198-209.

10. Chaterjeea A, Shuklaa S, Mishrab P, Rastogia A and Singh S. Prospects of in vitro production of thebaine in opium poppy (Papaver somniferum L.). Industrial Crops and Products 2010; 32: 668-70.

11. Yesil-Celiktas O, Gurel A and Vardar-Sukan F, Large scale cultivation of plant cell and tissue culture in bioreactors. 2010, Kerala: Transworld Research Network.

12. Jeong C S, Murthy H N, Hahn E J, Lee H L and Paek $\mathrm{K} \mathrm{Y}$. Inoculum size and auxin concentration influence the growth of adventitious roots and accumulation of ginsenosides in suspension cultures of Panax ginseng (C. A. Meyer). Acta Physiologiae Plantarum. 2009; 31;
09; 219-22.

13. Paek K, Murthy $\mathrm{H}$, Hahn $\mathrm{E}$ and Zhong J. Large scale culture of ginseng adventitious roots for production of ginsenosides. Advanced Biochemical Engineering Biotechnol. 2009; 113: 151-76.

14. Ballica R and Ryu D. Effects of rheological properties and mass transfer on plant cell bioreactor performance: production of tropane alkaloids. Biotechnology Bioengineering 1993; 42: 1181-89.

15. Wu S, Yu X, Lian M, Park $S$ and Piao X. Several factors affecting hypericin production of Hypericum perforatum during adventitious root culture in airlift bioreactors. Acta Physiologiae Plantarum. 2014; 36: 975-81.

16. Lee J, Seong E, Goh E, NY K and Yu C. Factors involved in mass propagation of Ginseng (Panax ginseng C. A. Meyer) using bioreactor system. J. Korean Society Applied Biological Chemistry 2009; 52: 466 - 71.

17. McClung $\mathrm{C}$ R. Circadian rhythms in plants. Plant Physiol. 2001; 52: 139 - 62.

18. Luschnig C. Auxin transport: $\mathrm{ABC}$ proteins join the club. Trends Plant Science 2002; 7 (8): 329 - 32. 
قوامى و همكاران

\title{
Optimization of Thebaine Production using Adventitious Roots of Papaver bracteatum Lindle. by Alteration of Aeration Volume and Temperature in Bioreactor
}

\author{
Qavami N (Ph.D.) ${ }^{1 *}$, Naghdi Badi H (Ph.D.), Qaderi A (Ph.D.), Mehrafarin A (Ph.D.), Khalighi- \\ Sigaroodi F (Ph.D.), Zare karizi AR (Ph.D.)
}

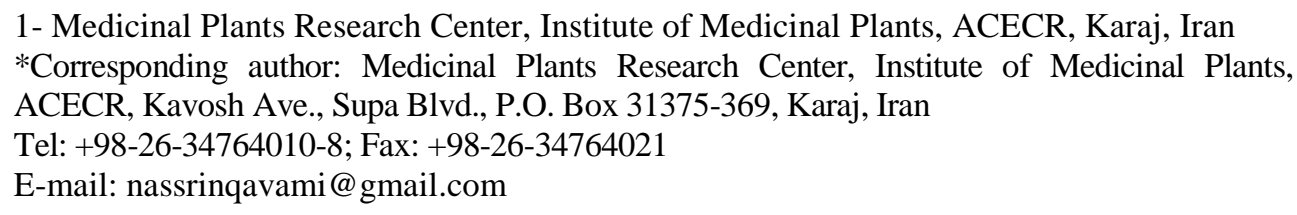

\section{Abstract}

Background: Nowadays, the optimization of the culture conditions in bioreactors is considered as an approach to produce secondary metabolites such as thebaine.

Thebaine is the dominant alkaloid in Iranian poppy that is used as a precursor for the synthesis of analgesic compounds.

Objective: Optimization of culture conditions of Papaver bracteatum adventitious roots in bioreactor for the scale-up thebaine production.

Methods: In this study, adventitious roots was induced from the stem explants and then cultured in a bubble column bioreactor. The research was conducted as a factorial experiment based on randomized complete design. The bioreactor temperatures were $14,20,26$ and $32{ }^{\circ} \mathrm{C}$, as well as aeration volumes were $0.05,0.1,0.2$ and $0.4 \mathrm{vvm}$.

Results: The results showed that the temperature and aeration volume had significant effect on root fresh weight and thebaine content. The highest root dry weight was related to aeration volume of $0.2 \mathrm{vvm}$ and temperature of $26^{\circ} \mathrm{C}$. The maximum content of thebaine was observed in aeration volume of $0.2 \mathrm{vvm}$ and temperature of $26^{\circ} \mathrm{C}$.

Conclusion: According to the results, aeration volume and temperature were two important factors for large-scale production of Papaver bracteatum biomass and thebaine in bioreactor conditions.

Keywords: Papaver bracteatum, Adventirious root, Bioreactor, Thebaine 